\title{
Genetic architecture and bottleneck analyses of Salem Black goat breed based on microsatellite markers
}

\author{
A. K. Thiruvenkadan ${ }^{1}$, V. Jayakumar ${ }^{2}$, P. Kathiravan ${ }^{3}$ and R. Saravanan ${ }^{4}$
}

1. Department of Animal Husbandry Statistics and Computer Applications, Veterinary College and Research Institute, Namakkal - 637 002, Tamil Nadu, India; 2. Veterinary Assistant Surgeon, Veterinary Dispensary, Department of Animal Husbandry, Namakkal - 637 001, Tamil Nadu, India; 3. Livestock Geneticist, Joint FAO/IAEA Division of Nuclear Techniques in Food and Agriculture, International Atomic Energy Agency, Vienna, Austria; 4. Department of Animal Genetics and Breeding, Veterinary College and Research Institute, Namakkal - 637 002, Tamil Nadu, India.

Corresponding author: A. K. Thiruvenkadan, e-mail: drthirusiva@gmail.com, VJ: drjaikumar007@gmail.com, PK: kathirvet@yahoo.co.in, RS: mrsagb@gmail.com

Received: 05-05-2014, Revised: 12-08-2014, Accepted: 19-08-2014, Published online: 27-09-2014

doi: 10.14202/vetworld.2014.733-737. How to cite this article: Thiruvenkadan AK, Jayakumar V, Kathiravan $P$, Saravanan R (2014) Genetic architecture and bottleneck analyses of Salem Black goat breed based on microsatellite markers, Veterinary World 7(9):733-737.

\begin{abstract}
Aim: The present study was undertaken in Salem Black goat population for genetic analysis at molecular level to exploit the breed for planning sustainable improvement, conservation and utilization, which subsequently can improve the livelihood of its stakeholders.

Materials and Methods: Genomic DNA was isolated from blood samples of 50 unrelated Salem Black goats with typical phenotypic features in several villages in the breeding tract and the genetic characterization and bottleneck analysis in Salem Black goat was done using 25 microsatellite markers as recommended by the Food and Agricultural Organization, Rome, Italy. The basic measures of genetic variation were computed using bioinformatic software. To evaluate the Salem Black goats for mutation drift equilibrium, three tests were performed under three different mutation models, viz., infinite allele model (IAM), stepwise mutation model (SMM) and two-phase model (TPM) and the observed gene diversity (He) and expected equilibrium gene diversity (Heq) were estimated under different models of microsatellite evolution.
\end{abstract}

Results: The study revealed that the observed number of alleles ranged from 4 (ETH10, ILSTS008) to 17 (BM64444) with a total of 213 alleles and mean of $10.14 \pm 0.83$ alleles across loci. The overall observed heterozygosity, expected heterozygosity, inbreeding estimate and polymorphism information content values were $0.631 \pm 0.041,0.820 \pm 0.024,0.233 \pm 0.044$ and $0.786 \pm 0.023$ respectively indicating high genetic diversity. The average observed gene diversities $(\mathrm{He})$ pooled over different markers was $0.829 \pm 0.024$ and the average expected gene diversities under IAM, TPM and SMM models were $0.769 \pm 0.026$, $0.808 \pm 0.024$ and $0.837 \pm 0.020$ respectively. The number of loci found to exhibit gene diversity excess under IAM, TPM and SMM models were 18, 17 and 12 respectively.

Conclusion: All the three statistical tests, viz., sign test, standardized differences test and Wilcoxon sign rank test, revealed significant deviation of Salem Black goats from mutation-drift equilibrium under IAM and TPM models, however, nonsignificant deviation under SMM model. The qualitative test of mode shift analysis supported the results under SMM indicating the absence of the genetic bottleneck in the recent past in Salem Black goats.

Keywords: bottleneck, genetic diversity, microsatellites, Salem Black.

\section{Introduction}

India is bestowed with a diverse indigenous goat population with 23 recognized breeds, which have been evolved by farmers over centuries for various utilities. Most of these breeds are developed for meat and milk. All these breeds are well adapted to the agro-climatic conditions prevailing in their respective native tracts, tolerant to tropical heat, relatively more resistant to tropical diseases and thrive well with meager feedstuff mostly crop residues. However, due to changing agricultural pattern some of these indigenous goats have declined over the past few decades. In recent years, microsatellites have been used successfully to define genetic relationships among different

Copyright: The authors. This article is an open access article licensed under the terms of the Creative Commons Attributin License (http:// creative commons.org/licenses/by/2.0) which permits unrestricted use, distribution and reproduction in any medium, provided the work is properly cited. livestock breeds around the word. Microsatellites display higher levels of variation and consequently enable population differentiation to be found more efficiently, so as to help breeders to implement rational decisions for conservation and improvement of valuable germplasm [1]. There are several studies on genetic diversity of goats, based on microsatellite markers [2-5]. The Salem Black is an important meat goat breed in the north-western part of Tamil Nadu, India. Salem Black goats are tall animals, completely black in color and reared mainly for meat [6]. This breed is primarily maintained by small and marginal farmers and landless laborers mostly for meat production. Breeding of these animals is highly unorganized, and this calls for urgent action to improve genetically as well as to conserve these goats. The genetic architecture and bottleneck analysis of Salem Black goat population has not been carried out in its native environment. Hence, microsatellite analysis was 
carried out to assess the genetic variation at molecular levels and to test for signatures of recent population bottlenecks in Salem Black goats.

\section{Materials and Methods}

Genomic DNA was isolated from blood samples of 50 unrelated Salem Black goats with typical phenotypic features in several villages in the breeding tract [7]. Although no parentage records were available, to ensure unrelatedness, animals were selected from distinct villages after interviewing the farmers in detail. A battery of 25 goat-specific microsatellite markers (OARFCB20, SRCRSP5, ILSTS029, OARJMP29, CSRD247, MAF70, ILSTS087, MCM527, OARAE129, ETH225, OARFCB304, ILSTS005, MAF65, ILST008, ETH10, BM1329, SRCRSP23, SPS113, MAF209, BM6444, OARFCB48, ILSTS011, SRCRSP8, SRCRSP9 and ILSTS033) were selected to generate allelic data. The polymerase chain reaction (PCR) amplification of microsatellite loci was carried out in a thermal cycler (Eppendorf, Germany) using cycling conditions as: $5 \mathrm{~min}$ at $94^{\circ} \mathrm{C}$, followed by 30 cycles of $45 \mathrm{~s}$ at $94^{\circ} \mathrm{C}, 35 \mathrm{~s}$ at annealing temperature (depending upon locus), $35 \mathrm{~s}$ at $72^{\circ} \mathrm{C}$ and final extension at $72^{\circ} \mathrm{C}$ for $10 \mathrm{~min}$. The genotyping of microsatellite markers was made by capillary electrophoresis using the automatic sequencer, and the data were captured using ABI 3130 of Applied Biosystems, India Data collection Software Version 4.0. The basic measures of genetic variation were computed using Microsatellite Analyzer version 3.15 [8]. The exact test for HardyWeinberg equilibrium was performed using Arlequin version 3.1 [9]. Polymorphism information content was estimated using GenAlEx program [10]. The variation between allelic diversity and heterozygosity was exploited as the basis for statistical tests to evaluate the mutation drift equilibrium of Salem Black goat population. To determine the significant number of loci with heterozygosity excess, three tests, namely, sign test, standardized differences test and Wilcoxon sign rank test were performed under three different mutation models. Furthermore, a qualitative test of mode shift was performed to evaluate the frequency distribution of alleles at different microsatellite loci using BOTTLENECK program [11].

\section{Results and Discussion}

All the 25 microsatellite loci amplified successfully in Salem Black goat breeds and produced definite patterns from which individual genotypes could be ascertained. The test for linkage disequilibrium between different combinations of loci under study showed significant deviations in four loci alone and hence they were removed, and the remaining 21 loci were retained for analysis.

The basic genetic diversity indices are presented in Table- 1 . The study revealed that a total of 213 distinct alleles across 21 loci were identified. The allelic polymorphism ranged between 4 (ETH10, ILSTS008) and 17 (BM64444) with a mean number of alleles of $10.14 \pm 0.83$. The mean observed number of allele recorded in this study was higher than the values reported in Barbari and Kanni Adu goats [5,12] and comparable to the value of 10.20 reported for Konkan Kanyal goats [13]. The high allelic diversity observed is probably due to no selection pressure and choice of samples based on random sampling. The

Table-1: Basic diversity indices of Salem Black goats at each microsatellite locu.

\begin{tabular}{|c|c|c|c|c|c|c|c|}
\hline \multirow[t]{2}{*}{ Locus } & \multirow{2}{*}{$\begin{array}{c}\text { Observed } \\
\text { number of alleles }\end{array}$} & \multicolumn{3}{|c|}{ Heterozygosity } & \multirow{2}{*}{$\begin{array}{l}P \text { value } \\
\text { (HW) }\end{array}$} & \multirow[t]{2}{*}{$\mathbf{F}_{\text {IS }}$} & \multirow[t]{2}{*}{ PIC } \\
\hline & & Observed & Expected & Nei & & & \\
\hline BM1329 & 9 & 0.744 & 0.856 & 0.852 & 0.099 & 0.126 & 0.828 \\
\hline BM6444 & 17 & 0.909 & 0.929 & 0.923 & 0.366 & 0.016 & 0.912 \\
\hline CSRD247 & 9 & 0.651 & 0.874 & 0.871 & 0.001 & 0.252 & 0.849 \\
\hline ETH10 & 4 & 0.409 & 0.574 & 0.572 & 0.000 & 0.284 & 0.477 \\
\hline ETH225 & 12 & 0.535 & 0.823 & 0.820 & 0.000 & 0.348 & 0.799 \\
\hline ILSTS005 & 8 & 0.674 & 0.840 & 0.836 & 0.001 & 0.193 & 0.808 \\
\hline ILSTS008 & 4 & 0.682 & 0.594 & 0.590 & 0.162 & -0.156 & 0.502 \\
\hline ILSTS029 & 8 & 0.524 & 0.729 & 0.726 & 0.061 & 0.278 & 0.677 \\
\hline ILSTS033 & 7 & 0.250 & 0.629 & 0.628 & 0.000 & 0.602 & 0.593 \\
\hline ILSTS087 & 8 & 0.825 & 0.858 & 0.852 & 0.164 & 0.032 & 0.829 \\
\hline MAF209 & 8 & 0.349 & 0.834 & 0.832 & 0.000 & 0.581 & 0.802 \\
\hline MAF70 & 15 & 0.886 & 0.903 & 0.898 & 0.188 & 0.013 & 0.884 \\
\hline MCM527 & 5 & 0.295 & 0.688 & 0.687 & 0.000 & 0.570 & 0.643 \\
\hline OARAE129 & 12 & 0.636 & 0.881 & 0.877 & 0.000 & 0.275 & 0.858 \\
\hline OARFCB20 & 10 & 0.523 & 0.862 & 0.859 & 0.000 & 0.392 & 0.837 \\
\hline OARFCB304 & 16 & 0.576 & 0.914 & 0.909 & 0.000 & 0.367 & 0.892 \\
\hline OARFCB48 & 9 & 0.674 & 0.848 & 0.844 & 0.000 & 0.201 & 0.819 \\
\hline SPS113 & 12 & 0.773 & 0.907 & 0.903 & 0.002 & 0.144 & 0.888 \\
\hline SRCRSP5 & 11 & 0.682 & 0.891 & 0.887 & 0.000 & 0.232 & 0.869 \\
\hline SRCRSP8 & 16 & 0.837 & 0.920 & 0.915 & 0.008 & 0.085 & 0.902 \\
\hline SRCRSP9 & 13 & 0.818 & 0.870 & 0.865 & 0.061 & 0.055 & 0.845 \\
\hline Mean & $10.14 \pm 0.83$ & $0.631 \pm 0.041$ & $0.820 \pm 0.024$ & $0.816 \pm 0.024$ & & $0.233 \pm 0.044$ & $0.786 \pm 0.023$ \\
\hline
\end{tabular}

PIC=Polymorphism information content, $\mathrm{HW}=$ Hardy-Weinberg, $\mathrm{F}_{\mathrm{IS}}=$ Inbreeding estimate 
mean observed and expected heterozygosities were $0.631 \pm 0.041$ and $0.820 \pm 0.024$ respectively. Genetic markers with polymorphism information content (PIC) values of $<0.25$ are considered to be less informative and those values more than 0.5 are reckoned as distinctly informative in population genetic studies [14]. Accordingly, none of the markers in the present study showed PIC values lower than 0.25 , indicating their suitability for assessing genetic variation. Further, the present set of microsatellite loci with a wide range of heterozygosity values reduces the risk of overestimating genetic variability that might occur if microsatellites exhibiting only high heterozygosity values were employed [15]. In the present study, about $81 \%$ of the loci showed positive deviation from Hardy-Weingberg equilibrium. The mean observed and expected heterozygosities obtained in this study is higher than that reported in other goat breeds $[5,12,16]$. The fairly high value of inbreeding estimate $\left(\mathrm{F}_{\mathrm{IS}}\right)$ indicated that some of the loci in this breed were homozygous presumably resulting from the mating between relatives and consequent genetic drift.

In order to test the mutation drift equilibrium in Salem Black goats, the three mutation models of microsatellite evolution were assumed, viz. infinite allele model (IAM), stepwise mutation model (SMM) and two-phase model (TPM) and all the models were tested using "sign test," a "standardized differences test" [17] and a "Wilcoxon sign-rank test" [18]. The distribution of expected gene diversity $\left(\mathrm{H}_{\mathrm{eq}}\right)$ within Salem Black goat under the assumption of constant size population was derived from the frequency of observed alleles for a given sample size. The expected gene diversities calculated under three mutation models, viz., IAM, SMM and TPM are presented in Table-2. The mean expected equilibrium gene diversity across 21 microsatellite loci under IAM, TPM and SMM were $0.769 \pm 0.026,0.808 \pm 0.024$ and $0.837 \pm 0.020$ respectively. The expected gene diversities $\left(\mathrm{H}_{\mathrm{eq}}\right)$ estimated under three models of microsatellite evolution were compared to the observed gene diversity (He) to establish the presence of gene diversity excess or deficit at each locus within Salem Black goat population.

Three statistical tests for each mutation model revealed that Sign rank test showed significant heterozygosity excess under IAM and TPM, thereby rejecting the null hypothesis of mutation drift equilibrium. However, in case of SMM, though heterozygosity excess was found in 12 of the 21 loci studied, it was not significant (Table-3). The results of the standardized difference test showed positive and significant $T_{2}$ values under IAM and TPM models, while it was negative and non-significant under SMM model. Similar results were obtained using Wilcoxon sign rank test with significant heterozygosity excess under IAM and TPM models and non-significant under SMM model. In the present study, all the three tests showed significant deviation under sign and standardized differences test and a non-significant deviation under SMM model. For any given data set, IAM predicts lower equilibrium gene diversity than SMM, and hence, it is more likely to indicate significant heterozygosity excess. Salem Black goats were found to deviate from equilibrium gene diversity under IAM and TPM models and under statistically more

Table-2: Estimated observed $\left(\mathrm{H}_{\mathrm{e}}\right)$ and expected $\left(\mathrm{H}_{\mathrm{eq}}\right)$ gene diversities under different mutation models of microsatellite evolution in Salem Black goats.

\begin{tabular}{|c|c|c|c|c|}
\hline \multirow[t]{2}{*}{ Locus } & \multirow{2}{*}{$\begin{array}{l}\text { Observed gene } \\
\text { diversity }\left(\mathrm{H}_{\mathrm{e}}\right)\end{array}$} & \multicolumn{3}{|c|}{ Expected equilibrium gene diversity $\left(\mathrm{H}_{\mathrm{eq}}\right)$} \\
\hline & & IAM & TPM & SMM \\
\hline BM1329 & 0.866 & 0.772 & 0.817 & 0.845 \\
\hline BM6444 & 0.939 & 0.911 & 0.925 & 0.934 \\
\hline CSRD247 & 0.884 & 0.768 & 0.817 & 0.847 \\
\hline ETH10 & 0.581 & 0.491 & 0.559 & 0.616 \\
\hline ETH225 & 0.833 & 0.843 & 0.874 & 0.894 \\
\hline ILSTS005 & 0.849 & 0.738 & 0.788 & 0.82 \\
\hline ILSTS008 & 0.601 & 0.502 & 0.553 & 0.614 \\
\hline ILSTS029 & 0.737 & 0.737 & 0.787 & 0.824 \\
\hline ILSTS033 & 0.637 & 0.697 & 0.754 & 0.79 \\
\hline ILSTS087 & 0.867 & 0.739 & 0.786 & 0.82 \\
\hline MAF209 & 0.844 & 0.74 & 0.787 & 0.823 \\
\hline MAF70 & 0.914 & 0.889 & 0.904 & 0.922 \\
\hline MCM527 & 0.696 & 0.575 & 0.633 & 0.696 \\
\hline OARAE129 & 0.891 & 0.843 & 0.875 & 0.892 \\
\hline OARFCB20 & 0.872 & 0.804 & 0.836 & 0.864 \\
\hline OARFCB304 & 0.921 & 0.901 & 0.916 & 0.929 \\
\hline OARFCB48 & 0.858 & 0.773 & 0.813 & 0.847 \\
\hline SPS113 & 0.918 & 0.845 & 0.874 & 0.893 \\
\hline SRCRSP5 & 0.902 & 0.818 & 0.858 & 0.881 \\
\hline SRCRSP8 & 0.93 & 0.901 & 0.917 & 0.929 \\
\hline SRCRSP9 & 0.88 & 0.86 & 0.887 & 0.904 \\
\hline Overall & $0.829 \pm 0.024$ & $0.769 \pm 0.026$ & $0.808 \pm 0.024$ & $0.837 \pm 0.020$ \\
\hline
\end{tabular}

IAM=Infinite alleles model, TPM=Two-phase model, SMM=Stepwise mutation model 
conservative SMM no deviation was noticed indicating no genetic basis for demographic bottleneck.

The mode-shift indicator test was also utilized as a second method to detect potential bottlenecks. This is a qualitative method for detection of the genetic bottleneck. In non-bottlenecked populations, a large proportion of rare alleles is expected. However, bottleneck events are expected to cause alleles with low frequency, i.e., rare alleles to become less abundant in the population than alleles with intermediate frequencies. In such cases, the plotting of proportion of different alleles against allele frequency classes will cause mode shift from the normal L-shaped distribution. The frequency distribution of alleles in Salem Black goat population followed the normal L-shaped curve as the alleles with the lowest frequency (0.0010.1 ) were found to be abundant (Figure-1). This distribution clearly shows that the studied population has not experienced a recent bottleneck. In general, few studies have reported on the possible occurrence of the genetic bottleneck based on microsatellite data, viz., Dexter, Bargur and African cattle breeds and Valais Blackneck goat [19-22]. Earlier studies on different Indian and Iranian goat breeds did not reveal any indication of recent occurrence of the genetic bottleneck $[1,5,12,13,23-25]$.

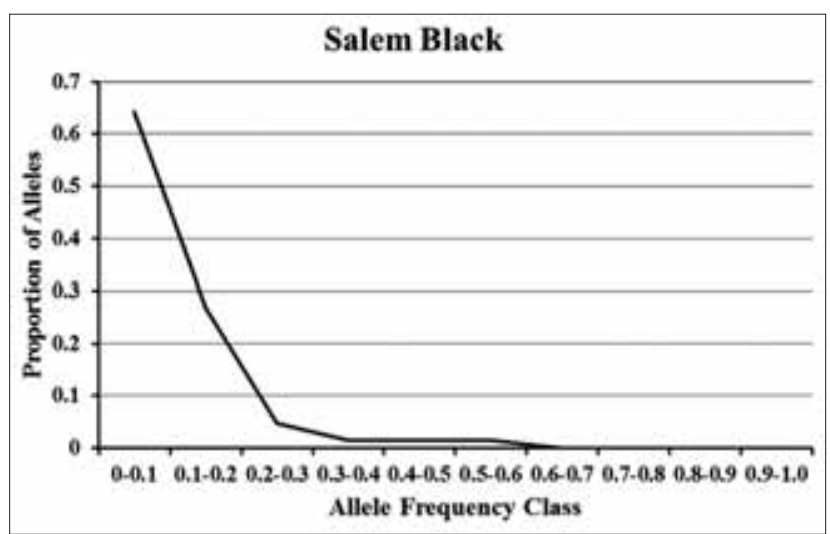

Figure-1: Allele frequency spectra of Salem Black goat showing normal L-shaped distribution and absence of recent genetic bottleneck.

Table-3: Different tests for mutation drift equilibrium in Salem Black goats.

\begin{tabular}{|c|c|c|c|}
\hline Test & IAM & TPM & SMM \\
\hline \multicolumn{4}{|l|}{ Sign test } \\
\hline $\begin{array}{l}\text { Observed number of loci with } \\
\text { He excess }\end{array}$ & 18 & 17 & 12 \\
\hline $\begin{array}{l}\text { Expected number of loci with } \\
\text { He excess }\end{array}$ & 12.70 & 12.72 & 12.41 \\
\hline$P$ value & 0.012 & 0.041 & 0.511 \\
\hline \multicolumn{4}{|l|}{ Standardized differences test } \\
\hline $\mathrm{T}_{2}$ value & 3.83 & 2.01 & -0.84 \\
\hline $\mathrm{P}$ value (One tail test for He excess) & 0.000 & 0.022 & 0.201 \\
\hline \multicolumn{4}{|l|}{ Wilcoxon sign rank test } \\
\hline $\mathrm{P}$ value (One tail test for He excess) & 0.000 & 0.015 & 0.473 \\
\hline
\end{tabular}

\section{Conclusion}

Thus, it can be concluded although conservatively based on SMM and qualitative test for mode shift that Salem Black goat population has not deviated from mutation drift equilibrium, indicating the absence of the genetic bottleneck in the recent past in Salem Black goats. However, the heterozygote deficiency observed in the population as a result of indiscriminate breeding is a cause for concern.

\section{Authors' Contributions}

AKT, PK and RS were involved in design of experiment. VJ carriedout the experiment under the supervison of AKT. PK analysed the results and guided interpretation of the results. AKT and PK collected the materials for the manuscript and prepared the first draft before being revised by all the authors. All authors read and approved the final manuscript.

\section{Acknowledgments}

The authors wish to express their sincere thanks to International Foundation for Science, Karlavagen $108,5^{\text {th }}$ Floor, SE-11526 Stockholm, Sweden for the financial support to carry out this research activities.

\section{Competing Interests} interests.

The authors declare that they have no competing

\section{References}

1. Mahmoudi, B., Esteghamat, O., Shahriyar1, A., and Babayev, M.S.H. (2012) Genetic characterization and bottleneck analysis of Korki Jonub Khorasan goats by microsatellite markers. J. Cell. Mol. Biol., 10: 61-69.

2. Aggarwal, R.A.K., Dixit, S.P., Verma, N.K., Ahlawat, S.P.S., Kumar, Y., Kumar, S., Chander, R. and Singh, K.P. (2007) Population genetic analysis of Mehsana goat based on microsatellite markers. Curr. Sci., 92: 1133-1137.

3. Rout, P.K., Joshi, M.B., Mandal, A., Laloe, D., Singh, L. and Thangaraj, K. (2008) Microsatellite-based phylogeny of Indian domestic goats. BMC. Genet., 9: 11, 2008.

4. Ramamoorthi, J., Thilagam, K., Sivaselvam, S.N. and Karthickeyan, A.M.K. (2009) Genetic characterization of Barbari goats using microsatellite markers. J. Vet. Sci., 10(1): $72-76$.

5. Dixit, S.P., Aggarwal, R.A.K., Verma, N.K., Vyas, M.K., Rana, J., Sharma, A. and Chander, R. (2011) Genetic variability and bottleneck analyses of Kanniadu goat breed based on microsatellite markers. Indian J. Anim. Sci., 81:40-43.

6. Thiruvenkadan, A.K. and Karunanithi, K. (2006) Characterization of Salem black goats in their home tract. Anim. Genet. Resour. Inf., 38: 67-75.

7. Miller, S.A., Dykes, D.D. and Polesky, H.F. (1988) A simple salting out procedure for extracting DNA from human nucleated cells. Nucleic. Acids. Res., 16(3): 1215.

8. Dieringer, D. and Schlötterer, C. (2003) Microsatellite analyzer (MSA): A platform independent analysis tool for large microsatellite data sets. Mol. Ecol. Notes., 3: 167-169.

9. Excoffier, L., Laval, G. and Schneider, S. (2005) Arlequin ver. 3.0: An integrated software package for population genetics data analysis. Evol. Bioinformatics. Online., $1: 47-50$.

10. Peakall, R. and Smouse, P.E. (2006) GENALEX 6: Genetic analysis in excel. Population genetic software for teaching and research. Mol. Ecol. Notes., 6: 288-295. 
11. Piry, S., Luikart, G. and Cornuet, J.M. (1999) Bottleneck: A computer program for detecting recent reductions in the effective population size using allele frequency data. $J$. Hered., 90: 502-503.

12. Sharma, R., Kumar, D., Pandey, A.K., Dixit, S.P. and Ahlawat, S.P.S. (2008) Genetic variability and bottleneck analysis of Barbari goat population using microsatellite markers. Indian J. Anim. Sci., 78: 391-396.

13. Mishra, P., Ali, A.S., Aggarwal, R.A.K., Dixit, S.P., Kawitkar, V.S., Dangi, P.S. and Verma, N.K. (2012) Genetic diversity and bottleneck analysis of Konkan Kanyal goats. Anim. Genet. Resour., 50: 43-48.

14. Botstein, D., White, R.L., Skolnick, M. and Davis, R.W. (1980) Construction of a genetic linkage map in man using restriction fragment length polymorphisms. Am J. Hum. Genet., 32: 314-331.

15. Wimmers, K., Ponsuksili, S., Hardge, T., Valle-Zarate, A., Mathur, P.K. and Horst, P. (2000) Genetic distinctness of African, Asian and South American local chickens. Anim. Genet., 31: 159-165.

16. Li, J.Y., Chen, H., Lan, X.Y., Kong, X.J. and Min, L.J. (2008) Genetic diversity of five Chinese goat breeds assessed by microsatellite markers. Czech. J. Anim. Sci., 53: 315-319.

17. Cornuet J.M. and Luikart, G. (1996) Description and power analysis of two tests for detecting recent population bottlenecks from allele frequency data. Genet., 144: 2001-2014.

18. Luikart GL, Allendorf FW, Cornuet JM, Sherwin WB. (1998) Distortion of allele frequency distributions provides a test for recent population bottlenecks. J. Hered., 89: 238-247.

19. Mburu, D.N. and Hanotte, O. (2005) Comparative genetic analysis of molecular diversity of African cattle. In: The Proceedings Of International Workshop On The Role Of Biotechnology For The Characterization And Conservation Of Crop, Forestry, Animal And Fishery Genetic Resources, 5-7 March, 2005, Villa Gualino, Turin, Italy.

20. Glowatzki-Mullis, M.L., Muntwyler, J., Baumle, E. and Gaillard, C. (2008) Genetic diversity measures of Swiss goat breeds as decision making support for conservation policy. Small. Rumin. Res., 74: 202-211.

21. Bray, T.C., Chikhi, L., Sheppy, A.J. and Bruford, M.Q. (2009) The population genetic effects of ancestry and admixture in a subdivided cattle breed. Anim. Genet., 40: 393-400.

22. Ganapathi, P., Rajendran, R. and Kathiravan, P. (2012) Detection of occurrence of a recent genetic bottleneck event in Indian hill cattle breed Bargur using microsatellite markers. Trop. Anim. Health Prod., 44(8): 2007-2013.

23. Tantia, M.S., Behl, R., Sheoran, N., Singh, R., and Vijh, R.K. (2007) Microsatellite data analysis for conservation of two goat breeds. Indian J. Anim. Sci., 74: 761-767.

24. Fatima, S., Bhonga, C.D, Ranka, D.N. and Joshi, C.G. (2008) Genetic variability and bottleneck studies in Zalawadi, Gohilwadi and Surti goat breeds of Gujarat (India) using microsatellites. Small Rumin. Res., 77: b58-64.

25. Mishra, P., Verma, N.K., Aggarwal, R.A.K. and Dixit, S.P. (2010) Breed characteristics and genetic variability in Changthangi goats. Indian J. Anim. Sci., 80: 1203-1208. 